\title{
La formación como escenario de integración multiverso y religante de la vida y la sociedad: temas y problemas emergentes en escenarios complejos
}

\author{
Astelio Silvera Sarmiento
}

A sumir los retos en la actual sociedad exigen para la Ciencia, la Tecnología y la Innovación, la posibilidad de abrir nuevas vías teóricas, epistemológicas y metodológicas, que allanen las brechas de conocimiento en la comprensión de los problemas y sus alternativas de solución. La educación no es ajena a este contexto, por cuanto sus estrategias de apropiación y gestión de saberes, permiten al ser humano poner en practica desde didácticas alternativas hasta políticas públicas de desarrollo humano y social (Sánchez e Higuera, 2018) convirtiéndola en un sistema complejo con interacciones de bucle, auto-organización y autotransformación.

La educación de la sociedad planetaria se enfrenta a problemas tan significativos como la comunicación intercultural desde la perspectiva del desarrollo de un país (Navarro y Santillan, 2018) en donde la formación se erige como herramienta inter y transdisciplinar para generar un nuevo enfoque de integración en la comunidad en donde se involucra a la sociedad a partir de sus necesidades y deseos expresados (p. 33), de esta manera, se configura un entretejido sistémico de conocimientos, estableciendo una red de relaciones y conexiones con el medio cultural, social, económico, político y natural, con la finalidad de cumplir el precepto de la contextualización.

Los últimos dos siglos han lanzado desafíos a la misión de la humanidad y la sociedad misma, accionando virtuosamente la toma de decisiones, como una etapa caracterizada de transición entre la evolución del ser y el horizonte de desarrollo sostenible e inclusivo del Buen Vivir. Esto implica para las ciencias un hacer de gestión del conocimiento, en donde un proceso de investigación se posiciona como un escenario de aplicabilidad eco-social y ecosofica (García y Garcés, 2018) agregándole valor a la condición humana, al tiempo que complementa la acción fundamental de la escuela (formal y social) con aplicación específica/general inmediata, llevando al ser humano hacia nuevos descubrimientos y conocimientos, apropiación social del saber y la ciencia (Silvera, et. al., 2016), y acciones promovedoras de innovación científica y tecnológica que ofrezcan un nuevo enfoque en el saber y en el saber hacer.

Los argumentos interdisciplinares de las humanidades y las ciencias sociales, justifican las diversas oportunidades para construir proyectos educativos y pedagógicos, a través de los cuales se inserte al ser en un escenario de interacción permanente entre la fundamentación del saber disciplinar y la actividad investigativa, consideradas como espacios relevantes para fundamentar las propuestas de cambio y transformación social y cultural.

Es preciso, devolver el protagonismo del conocimiento a aquel que había sido excluido por un objetivismo epistemológico ciego. Se trata de incluir en toda observación, en todo acto de conocimiento y de aprendizaje, la voluntad de la auto-observación, el auto-conocimiento, el auto-aprendizaje del observador, del conocedor, del aprendiz; es el principio del círculo creativo para el ejercicio de lo que desde la antigüedad se ha denominado autonomía. 
Son muchos los problemas que deben convertirse en objeto de investigación en la vida cotidiana del ser y sus áreas de trabajo o estudio; no obstante, gran parte de los objetos de investigación o análisis critico (saber popular) están relacionados con problemas contextuales, que se manifiestan diariamente la superación de la retórica de los discursos y teorías que no se insertan en la realidad, sino que por el contrario se definen como abstracciones aspiracionales de modelos poco referenciales en la vida social y comunitaria.

En consecuencia, la perspectiva de flexibilidad, transversalidad y complejidad de la comprensión de la realidad cobra una gran fuerza, si se tiene en cuenta que muchos de los escenarios académicos, se desarrollan como expresión de un proceso deliberativo y reflexivo de la vida en sociedad, generando saberes, intenciones, y actividades (técnicas, científicas, sociales y culturales) que configuran el ideario de una cosmovisión del mundo, forjada a través de valores, exento de tensiones, intereses y posiciones encontradas y contradictorias, lo que posibilita una transversalidad en el contexto de la flexibilidad curricular, social y política, en donde el ser es protagonista, al ser capaz de ejercer una influencia en los múltiples y profundos diálogos sobre los sistemas que se imbrican en el mundo moderno. 


\title{
Training as a scenario of the multiverse and combining life and society: issues and emerging problems in complex scenarios
}

\begin{abstract}
Astelio Silvera Sarmiento
T

o assume the challenges in the current society demand for Science, Technology and Innovation, the possibility of opening new theoretical, epistemological and methodological approaches, that smoothes the knowledge gaps in understanding problems and their solution alternatives. Education is not alien to this context, because its strategies of appropriation and management of knowledge allow the human being to put into practice from alternative didactics to public policies of human and social development (Sánchez and Higuera, 2018) turning it into a complex system with loop interactions, self-organization and self-transformation.
\end{abstract}

The education of planetary society faces significant problems such as intercultural communication from the perspective of the development of a country (Navarro and Santillan, 2018) where training is an inter and transdisciplinary tool to generate a new approach to integration in the community where society is involved based on their expressed needs and wishes (p. 33), in this way, a systemic interweaving of knowledge is configured, establishing a network of relationships and connections with the cultural, social, economic, political, and natural environment, in order to fulfil the precept of contextualization.

The last two centuries have launched challenges to the mission of humanity and society itself, virtuously triggering decision-making, as a stage characterized by a transition between the evolution of being and the horizon of sustainable and inclusive development of Good Living. This implies for the sciences a knowledge management approach, where a research process is positioned as a scenario of eco-social and ecosophic applicability (García and Garcés, 2018) adding value to the human condition, while complementing the action fundamental of the school (formal and social) with immediate specific / general application, leading the human being towards new discoveries and knowledge, social appropriation of knowledge and science (Silvera, et al., 2016), and actions promoting scientific innovation and technology that offer a new focus on knowledge and know-how.

The interdisciplinary arguments of the humanities and the social sciences, justify the diverse opportunities to build educational and pedagogical projects, through which the being is inserted into a scenario of permanent interaction between the foundation of disciplinary knowledge and research activity, considered as relevant spaces to support proposals for change and social and cultural transformation.

It is necessary to return the prominence of knowledge to one who had been excluded by blind epistemological objectivism. It is about including in every observation, in every act of knowledge and learning, the choice of self-observation, self-knowledge, the self-learning of the observer, the knower, the apprentice; It is the beginning of the creative circle for the exercise of what has been called autonomy since antiquity.

There are many problems that must become the object of research in the daily life of the being and

Pensamiento Americano Vol. 11 - No. 21 • Julio-Diciembre • Corporación Universitaria Americana • Barranquilla, Colombia • ISSN: 2027-2448 . http://publicaciones.americana.edu.co/index.php/pensamientoamericano/index 
its areas of work or study; However, a large part of the objects of research or critical analysis (popular wisdom) is related to contextual problems, which manifest daily the overcoming of the rhetoric of discourses and theories that are not inserted in reality, but on the contrary they are defined as aspirational abstractions of little referential models in social and community life.

Consequently, the perspective of flexibility, transversality and complexity of the understanding of reality takes on great strength, if one takes into account that many of the academic scenarios are developed as an expression of a deliberative and reflective process of life in society, generating knowledge, intentions, and activities (technical, scientific, social, and cultural) that shape the ideology of a worldview, forged through values, free of tensions, interests, and conflicting and conflicting positions, which allows a transversality in the context of curricular, social and political flexibility, where the being is the protagonist, being able to exert an influence in the multiple and deep dialogues about the systems that overlap in the modern world. 


\title{
A formação como cenário de integração multiverso e religante da vida e da sociedade: temas e problemas emergentes nos cenários completos
}

\author{
Astelio Silvera Sarmiento
}

A ssumir os desafios que a sociedade atual exige para a Ciência, a Tecnologia e a Inovação, a possibilidade de abrir novas vias teóricas, epistemológicas e metodológicas, que preencham as lacunas de conhecimento no entendimento dos problemas e suas alternativas para solucioná-los. A educação não está alheia a este contexto, enquanto suas estratégias de apropriação e gestão de saberes permitem ao ser humano colocar em prática desde as didáticas alternativas até as políticas públicas de desenvolvimento humano e social (Sánchez \& Higuera, 2018), convertendo-as em um sistema completo com interações, auto-organização e autotransformação.

A educação da sociedade enfrenta problemas tão significativos como a comunicação intercultural desde a perspectiva do desenvolvimento de um país (Navarro \& Santillan, 2018), onde a formação emerge como ferramenta inter e transdisciplinar para gerar um novo enfoque de integração na comunidade onde envolve-se a sociedade a partir de suas necessidades e desejos expressos (p.33). Assim, desta forma, se configura um tecido sistêmico de conhecimentos, estabelecendo uma rede de relações e conexões com o meio cultural, social, econômico, político e natural, com a finalidade de cumprir o preceito da contextualização.

Os dois últimos séculos lançaram desafios para a humanidade e a própria sociedade, acionando virtuosamente a tomada de decisões, como uma etapa caracterizada de transição entre a evolução do ser e o horizonte do desenvolvimento sustentável e inclusive do Bom Viver. Isto implica para as ciências um fazer de gestão de conhecimento, onde um processo de pesquisa se posiciona como um cenário de aplicabilidade eso-social e ecosófica (García \& Garcés, 2018), agregando valor à condição humana, ao mesmo tempo em que complementa a ação fundamental da escola (formal e social) com a aplicação específica/geral imediata, levando o ser humano a novos descobrimentos e conhecimentos, apropriação social do saber e da ciência (Silvera, et.al, 2016), e ações promovedoras de inovação científica e tecnológica que ofereçam um novo enfoque no saber e no saber fazer/realizar.

Os argumentos interdisciplinares das humanidades e das Ciências Sociais justificam as diversas oportunidades para construir projetos educativos e pedagógicos, através dos quais se inserte o ser em um cenário de interação permanente entre a fundamentação do saber disciplinar e a atividade de pesquisa, consideradas como espaços relevantes para fundamentar as propostas de mudança e transformação social e cultural.

É preciso devolver o protagonismo do conhecimento aos que haviam sido excluídos por um objetivismo epistemológico cego. Se trata de incluir em toda observação, em todo ato de conhecimento e de aprendizagem, a vontade da auto-observação, do autoconhecimento, a autoaprendizagem do observador, do conhecedor, do aprendiz; é o princípio do círculo criativo para o exercício do que se denominou, desde a Antiguidade, de autonomia. 
São muitos os problemas que devem ser convertidos em objeto de pesquisa na vida cotidiana do ser y suas áreas de trabalho ou estudo; não obstante, grande parte dos objetos de pesquisa ou análises crítico (saber popular) estão relacionados com problemas contextuais, que se manifestam diariamente na superação da retórica dos discursos e as teorias que nos insertam dentro da realidade, mas ao contrário se defendem como abstrações aspiracionais de modelos pouco referenciais na vida social e comunitária.

Em consequência, a perspectiva da flexibilidade, transversalidade e complexidade da compreensão da realidade cobra uma grande força, tendo em conta que muitos dos cenários acadêmicos, se desenvolvem como expressão de um processo deliberativo e reflexivo da vida em sociedade, gerando saberes, intenções e atividades (técnicas, científicas, sociais e culturais) que configuram o ideário de uma cosmovisão do mundo, forjada através dos valores, isento de tensões, interesses e posições encontradas e contraditórias, o que possibilita uma transversalidade no contexto da flexibilidade curricular, social e política, onde o ser é protagonista ao ser capaz de exercer uma influência nos múltiplos e profundos diálogos sobre os sistemas que se imbricam no mundo moderno. 
Arias, H., Guevara, C., Jadan, J. \& Bonilla, D. (2018). Una mirada a la investigación a través de open journal system y sistemas lectores de pantalla. Pensamiento Americano, 11(21), 1-10. DOI: http://dx.doi. org/10.21803\%2Fpenamer.11.21.521

Fraga, E. (2017). JOSÉ INGENIEROS, INTELECTUAL. ENTRE LA CIENCIA, LA CULTURA Y LA POLÍTICA. Pensamiento Americano, 10(18). Recuperado a partir de http://publicaciones.americana.edu.co/ index.php/pensamientoamericano/article/view/45

García, M., \& Garcés, L., (2018). La construcción del Oikos como estética de la existencia en Michel Serres: del espacio común a una experiencia personal. Pensamiento Americano, 11(21 ), 56-63. DOI: http://dx.doi.org/10.21803\%2Fpenamer.11.21.525

Martínez, B., \& Gorjón, G., (2018). Prácticas restaurativas en el marco jurídico mexicano con enfoque a una cultura de paz. Pensamiento Americano, 11(21), 64-80. DOI: http://dx.doi. org/10.21803\%2Fpenamer.11.21.526

Navarro, A., Padilla, C. \& Santillán J., (2018). La interculturalidad en el aprendizaje y la comunicación del diseño social. Pensamiento Americano, 11(21), 30-44 DOI: http://dx.doi. org/10.21803\%2Fpenamer.11.21.523

Sánchez, P., Higuera, D., (2018). Formación de políticas públicas para la garantía de derechos humanos. Pensamiento Americano, 11(21), 11-29. DOI: http://dx.doi.org/10.21803\%2Fpenamer.11.21.522

Silvera, A., Correa, C. \& Garcés, L. (2018). Resignificación del tejido social en la relación escuela comunidad: un enfoque investigativo complejo e interdisciplinar. Revista Espacios. pp. 2

Silvera, A. (2017). Experiencias de formación ciudadana en la educación básica: resignificación de la relación escuela-comunidad. En Educación Emergente, El paradigma del Siglo XXI, (Com) González, J. 90-101.

Silvera, A., Corredor, A., Pineda-Carreño, M., Pérez, H. \& Salazar, R. (2016). Resignificación del tejido social: formación de ciudadanos eco-lógicos a través de la integración dinámica de las neurociencias. Producción + Limpia, 11(1), 129-140. 